\title{
Osobowe źródła Cioranowskiego sceptycyzmu i pesymizmu
}

DOI: http://dx.doi.org/10.12775/RF.2014.015

Stanami, które w dużym stopniu wpłynęły na ukształtowanie się Cioranowskiej tożsamości i pesymistycznej postawy wobec człowieka i świata, a także w pełni uświadomiły rumuńskiemu myślicielowi daremność uciekania się do filozofii akademickiej, były bezsenność i nuda. Ich rolę $\mathrm{w}$ intelektualnym i osobowościowym rozwoju autora Ćwiartowania można porównać do dwóch skrzydeł jednych wrót, które otwierając się, raz przemiennie, a innym razem jednocześnie, dawały mu dostęp do doświadczeń nieznanych innym, stanowiących źródło odkryć poznawczych i w ten sposób uzupełniających egzystencjalny i myślowy krajobraz pesymizmu Emila Ciorana o kolejne złowrogie prawdy. Chociaż pojawiały się one $\mathrm{w}$ życiu rumuńskiego myśliciela $\mathrm{z}$ różną częstotliwościa, nie miały charakteru przejściowego i - ze względu na doniosłość towarzyszących im objawień - były stale wszechobejmującą i wszechokreślającą rzeczywistością. Jako skrajne doświadczenia negatywności dyskwalifikowały codzienność z jej urokami i zmuszały Ciorana do konfrontacji z istnieniem pozbawionym jakichkolwiek punktów oparcia.

Autor Brewiarza zwyciężonych cierpiał na bezsenność około ośmiu lat, od 17 do 25 roku życia ${ }^{1}$, choć, jak wynika z notatek zamieszczonych w Cahier de Talamanca, towarzyszyła mu ona również w wieku dojrzałym $^{2}$. Sam podkreślał, że brak snu był największym dramatem jego ży-

1 Relacje Ciorana na temat tego, kiedy zaczął cierpieć na bezsenność, są sprzeczne. Podczas gdy w rozmowie z Helgą Perz podaje, że miał wtedy 16 lub 17 lat, w innym miejscu twierdzi, że po raz pierwszy doświadczył braku snu w roku 1930 w Ocna Sibiului, gdzie jeździł wraz z ojcem na kuracje gorącymi kąpielami. Por.

E. Cioran, Scrisori către cei de-acasă, Humanitas, Bucureşti 2010, s. 139.

2 Por. idem, Cahier de Talamanca, Éditions Gallimard, Paris 2000, s. 30, 36, 40. 
cia, a te kilka lat, w trakcie których błąkał się samotnie nocą po Sybinie, naznaczyło go na resztę dni i zadecydowało o charakterze jego twórczości ${ }^{3}$. Podczas gdy wcześniej wszystko, co nie było filozofia, uważał za grzech lub śmierć, wyłącznie abstrakcji przypisywał „puls życia” ${ }^{4}$ oraz gardził sferą aktywności i uczuć, wraz z nadejściem bezsenności dostrzegł, że żaden system i idea nie są w stanie pomóc mu w jego cierpieniach, związanych z nieprzerwaną aktywnością umysłu wyzbytego nocnych pauz. Tracąc sen i źródło pewności, w jego przypadku w postaci filozofii, został tym samym pozbawiony egzystencji, którą wiedzie przeważająca część ludzkości.

Zwykły człowiek, niemający kłopotów z bezsennościa, budzi się rano, spędza cały dzień pracując, po czym, zmęczony, kładzie się spać, wstając zaś następnego dnia, odnosi wrażenie, jakby wszystko znów zaczynało się od nowa. We śnie zapomina o zmartwieniach, przeciwnościach losu i obsesjach, tak iż jego życie zachowuje przyjemną nieciągłość, dającą złudzenie nieustannej regeneracji i odradzania się. Bezsenność eliminuje je i odbierając sen, jednocześnie pozbawia zbawiennych przerw, które pozwalają zapomnieć i dzięki którym życie staje się znośne, jak również zmusza umysł oraz ciało do wyczerpującej przytomności. Będąc nieznośną udręką fizyczną i umysłową wpędza człowieka w skrajne nerwowe napięcie i czyni z niego widmo, a świat $\mathrm{i}$ istnienie przekształca $\mathrm{w}$ ich własny cień, tak iż po każdej bezsennej nocy przechodnie przypominają bardziej automaty niż ludzi, a cały spektakl życia odbywa się w sposób mechaniczny i pozbawiony spontaniczności ${ }^{5}$. W wywiadzie z Michaelem Jakobem Cioran powiedział:

bo życie da się znosić tylko dzięki nieciągłości. Dlaczego naprawdę śpimy? Nie tyle, żeby odpocząć, ile raczej po to, by zapomnieć. Facet, który wstaje rano po przespanej nocy, ma złudzenie, że coś się rozpoczyna. Jeśli jednak przez całą noc pan czuwa, nie zaczyna pan niczego. O ósmej rano jest pan w takim samym stanie jak o ósmej wieczorem, a cała pańska perspektywa nieuchronnie się zmienia ${ }^{6}$.

Odbierając możliwość odnowy sił witalnych i wybijając z życiowego rytmu, bezsenność w swoisty sposób dematerializuje egzystencję, od-

3 Pierwsza książka Ciorana, Na szczytach rozpaczy, miała być jego ostatnią i czymś w rodzaju testamentu, gdyż myślał, że pod wpływem bezsenności niedługo popełni samobójstwo. Por. idem, Rozmowy z Cioranem. Z Cioranem rozmawiają: François Bondy, Fernando Savater, Helga Perz [...], przeł. I. Kania, Wydawnictwo KR, Warszawa 1999, s. 232-233.

4 Por. idem, Zarys rozkładu, przeł. M. Kowalska, Wydawnictwo KR, Warszawa 2006, s. 233.

5 Por. idem, O niedogodności narodzin, przeł. I. Kania, Oficyna Literacka, Kraków 1996, s. 45.

6 Idem, Rozmowy z Cioranem, s. 235-236. 
rywa człowieka od ciała i sprowadza do zwykłej, pozbawionej energii, bezsilnej powłoki ${ }^{7}$. Kto został nią dotknięty, rozpada się, opróżnia się ze swej substancji i rozpuszcza niemal do całkowitego unicestwienia. Odcięty od refleksji i działania ${ }^{8}$, traci wszelką orientację i przenosi się w inny wymiar czasowy, gdzie każda noc jest podobna do innych i przedłuża się w nieskończoność. Podczas gdy osoba zdrowa potrafi włączyć się w nurt teraźniejszości i nie uświadamia sobie upływu czasu, jest z nim złączona, ona sama jest czasem, człowiekowi dotkniętemu bezsennością zostaje odebrane naiwne odczucie czasu. Przestając pojmować różnicę dzielącą noc i dzień, odnosi on wrażenie, jakby czas się od niego oddzielał. Samotny, umieszczony gdzieś między materią a snem, rejestruje i przeżywa przemijanie czasu, czas w sobie, odstały, odcedzony ze zdarzeń, istot i rzeczy, zredukowany do czystego przepływu, bez podziału na chwile9. Czas ten ledwie się wlecze, ale nie postępuje, przybiera postać czegoś zewnętrznego, w swoisty sposób stawiając człowieka poza przyczynowością. Wszystko znika, wszędzie wsącza się cisza, zmysły zwracają się ku światu zewnętrznemu, ale ten staje się próżny, ucieka, oddala się od nas, aż w końcu znajdujemy się poza jego obrębem oraz poza obrębem wszystkich żyjących ludzi, i - co gorsza - nie możemy się do tego świata ani czasu na powrót włączyćc ${ }^{10}$. Docieramy w ten sposób do negatywnej granicy życia, jesteśmy niezdolni do realizacji jakichkolwiek projektów i do włączenia się w historię, a także zdajemy sobie sprawę z niemożności tego życia, która rozprasza ostatnie złudzenia i czyni nas obserwatorami własnego upadku. Jak wyczerpujące są te chwile, świadczy fragment z książki O niedogodności narodzin, w którym Cioran napisat:

Bywają bezsenne noce, których nie mógłby wymyślić najzdolni ijs zy oprawca. Wychodzimy z nich potrzaskani na kawałki, osłupiali, ogłupiali, bez wspomnień ani przeczuć, nie wiedząc, kim jesteśmy. Wtedy światło dzienne wydaje się zarówno niepotrzebne, jak zgubne, gorsze nawet od nocy ${ }^{11}$.

Pozostaje nam wyłącznie przytomność myśli, a więc wyostrzona do granic możliwości świadomość siebie i świata w każdym miejscu i cza-

7 Por. N. Parfait, Cioran, ou, le défi de l'être, Éditions Desjonquères, Paris 2001, s. 24.

8 „Nie sposób cierpieć na bezsenność i wykonywać jakiś zawód: jeśli w mojej młodości moi rodzice nie fin a n ow alib y mojej bezsenności, z całą pewnością byłbym popełnił samobójstwo". E. Cioran, Wyznania i anatemy, przeł. K. Jarosz, Zielona Sowa, Kraków 2006, s. 10.

9 Por. idem, Zeszyty, przeł. I. Kania, Wydawnictwo KR, Warszawa 2004, s. 778.

10 Por. idem, Rozmowy z Cioranem, s. 73.

11 Idem, Zeszyty, s. 67-68. 
sie. Odczuwana w sposób ciągły, staje się największym nieszczęściem, ciężarem, który sprawia, że człowiek cierpi ponad miarę z najbardziej błahego powodu, rozpamiętuje rany i urazy, nie pozwalając im się zabliźnić, oraz zamienia się $\mathrm{w}$ niewolnika obsesji, mających organiczny charakter ${ }^{12}$. Jedynym lekarstwem na nia, sposobem na odzyskanie sił i zapomnienie zastałego, ale wciąż destrukcyjnego czasu jest, według Ciorana, codzienna kuracja nieświadomością, a więc niemal nieosiągalnym dla cierpiącego na bezsenność snem ${ }^{13}$. Zasypiając, włączamy się w anonimowy nurt życia, niejako przestajemy być ludźmi i uczestniczymy w stanie jednoczesnej pełni i nicości, w stanie sprzed indywiduacji, w którym łączymy się z czymś pierwotnym, bliskim materii i naszych początkó $w^{14}$. Z kolei budząc się, $w$ jednym momencie przechodzimy kilka miliardów lat życia na Ziemi, zostajemy wygnani, opuszczamy prawdziwy i jedyny możliwy w naszym przypadku raj, czyli nieświadomośćc 15 .

Zdaniem Ciorana różnica między rajem a piekłem jest taka, że $\mathrm{w}$ raju można spać kiedy się chce, natomiast $\mathrm{w}$ piekle - nigdy ${ }^{16}$. Bezsenność, jako jeden z najbardziej wyjaławiających stanów negatywnych, rodzi poczucie agonii, wiecznego i nieuleczalnego smutku oraz absolutnej rozpaczy i nie wydaje się prawdopodobne, aby ktoś, kto na nią cierpi, mógł kochać życie bez sporej domieszki nienawiści. Gdyby odebrać ludzkości sen, doszłoby do rzezi na niespotykaną dotąd skalę, a historia dobiegłaby kresu. Rumuński myśliciel porównuje bezsenną noc do „Wszechświata w żałobie” i „ogromu nieuchronności”"17, a o ludziach dotkniętych brakiem snu sądzi, że żyją w poczuciu bezustannego ukrzyżowania i siłą rzeczy każdy z nich jest jeśli nie samobójca, to przynajmniej teoretykiem samobójstwa ${ }^{18}$. Co więcej, brak snu, ze względu na potencjał rozbudzania świadomości, jest dla niego tak istotny, że dzieli on umysłowości na dzienne i nocne, czuwające i śpiące, oraz twierdzi, że

12 Cioran uwolnił się od bezsenności dzięki wysiłkowi fizycznemu. Na kartach swych książek często wspomina, jak podczas pierwszych lat we Francji przemierzał rowerem dziennie nawet po 100 kilometrów.

13 "Jedynym celem snu jest zapomnienie czasu, demonicznej zasady, która w nim drzemie". E. Cioran, Zmierzch myśli, przeł. A. Dwulit, Wydawnictwo KR, Warszawa 2004, s. 17.

14 W Zeszytach Cioran napisał: „Ktoś pragnący wiedzieć, czym jest życie i ile jest ono warte, powinien pamiętać, że jedynym, co nas z nim godzi, jest sen, tzn. to, co życiem nie jest, co jest jego zaprzeczeniem". Idem, Zeszyty, s. 237.

15 Por. idem, Cwiartowanie, przeł. M. Falski, Wydawnictwo KR, Warszawa 2004, s. 154.

16 Por. idem, Na szczytach rozpaczy, przeł. I. Kania, Oficyna Literacka, Kraków 1992, s. 126.

17 Idem, Święci i łzy, przeł. I. Kania, Wydawnictwo KR, Warszawa 2003, s. 174.

18 Por. idem, O niedogodności narodzin, s. 13. 
reprezentują one dwa zawsze odrębne „podgatunki bytów” ${ }^{19}$, niezdolne wejść ze sobą w kontakt, gdyż tak bardzo różnią się swymi prawdami i wyobrażeniami na temat człowieka i świata ${ }^{20}$. Wspomina, że kiedy cierpiał na brak snu, gardził absolutnie wszystkimi i postrzegał ich jako zwierzęta ${ }^{21}$, które pozwalają sobie na luksus regularnej ucieczki w stan nieświadomości. Nieprzerwane czuwanie i znajomość dramatu świadomości sprawiły, że przestał uważać się za część pospolitej ludzkości i zaczął rozwijać w sobie dumę jasności czy też ostrego widzenia, nakazującą mu czuć się jednocześnie faworyzowanym i ukaranym, napiętnowanym przekleństwem i dostępującym zaszczytu, a innych traktować zarazem z zazdrością i pogardąa 22 . Przekonany o tym, że bezsenność jest czymś na kształt wzbogacającej klęski, która otworzyła mu oczy, a jego spojrzenie na naturę rzeczy wynika w głównej mierze z nocnych czuwań, napisał:

Bezsenność obdziela nas światłem, którego nie chcemy, do którego jednak nieświadomie tęsknimy. Domagamy się go mimo woli, wbrew woli. W świetle tym - z uszczerbkiem dla zdrowia - poszukujemy czegoś innego, prawd niebezpiecznych i niszczących, tego wszystkiego, co sen przed nami skrywał. Bezsenne noce odbierają nam wszakże to, co łatwe i złudne, jedynie po to, by postawić nas przed zamkniętym horyzontem: oświetlają jedynie nasze własne ślepe uliczki. Uwalniając nas, zarazem skazują. Dwuznaczność ta nierozerwalnie łączy się z doświadczeniem nocy ${ }^{23}$.

Cioran przyznaje, że wszystko, co napisał, przyszło mu na myśl $\mathrm{w}$ trakcie bezsennych nocy, podczas których nic już nie istnieje i zostajemy sam na sam z cisza, wiecznością i pustką ${ }^{24}$. Noc sprawia, że im bardziej oddalamy się od świata, tym bliżej jesteśmy samych siebie i tym bardziej czujemy się solidarni z własnymi utrapieniami. Niezajęci niczym, co mogłoby nas odciągać od kwestii najistotniejszych dla naszej egzystencji, maksymalnie skupieni, szczerzy i bezkompromi-

19 Idem, Wyznania i anatemy, s. 62.

20 Por. idem, Zeszyty, s. 779.

21 Zdaniem Ciorana bezsenność nie dotyczy zwierząt, ale gdyby im nie pozwolić spać, w ich naturze natychmiast zaszłaby zmiana, doświadczyłyby wrażeń swoiście ludzkich i szybko dogoniłyby, a nawet zastąpiłyby człowieka. Por. idem, Wyznania i anatemy, s. 34 .

22 Chociaż Cioran początkowo przyznał sobie monopol na jasność, a nawet całe życie mówił o sobie, że jest człowiekiem „normalnym”, czyli w pełni świadomym swej sytuacji egzystencjalnej i pozbawionym złudzeń odnośnie do końca przygody, jaką jest życie, to jednak jego stanowisko z czasem łagodniało i wyostrzoną świadomość przyznawał wszystkim ludziom nieszczęśliwym. Por. idem, Les continents de l'insomnie. Entretien avec E. M. Cioran, w: G. Liiceanu, Itinéraires d'une vie: E. M. Cioran, Éditions Michalon, Paris 1995, s. 131.

23 E. Cioran, Ćwiczenia z zachwytu, przeł. J. M. Kłoczowski, Spółdzielnia Wydawnicza "Czytelnik”, Warszawa 1998, s. 119.

24 Por. idem, Rozmowy z Cioranem, s. 142. 
sowi względem siebie i świata, zaczynamy zgłębianie tychże kwestii. Cisza przywraca nas istotności, daje poczucie bezpieczeństwa, a nawet suwerenności, dzięki czemu wchodzimy w obszar refleksji najbardziej autentycznej i osobistej, spowiedzi z samego siebie samemu sobie ${ }^{25}$. Nie musimy się już pilnować, nie boimy się konsekwencji swoich myśli, nie dbamy też o to, czy przyniosą nam one pociechę, czy też pogrążą nas jeszcze bardziej. Upajamy się ich tajemniczą precyzją i niepokojącą lakonicznościa, a gdy już raz się pojawia, są - podobnie jak wyrok - myślami bez odwołania. Oprócz tego, że posiadają aspekt niszczący, stają się również czymś twórczym, siłą napędzającą istnienie, kryją w sobie głębię i potrafią nadać ją innym aktom naszego życia, stanowiąc początek wielkich objawień i wielkiej przemiany ${ }^{26}$. W ten sposób, dopiero na ruinach samych siebie, dochodząc - przez wyczerpanie, cierpienie i świadomość odczuwaną jako nieznośny nadmiar - do najgłębszych pokładów własnej egzystencji, dowiadujemy się prawdy o istnieniu oraz o tym, kim w rzeczywistości jesteśmy i jakie miejsce jest nam należne.

Bezsenność, chociaż pokazała Cioranowi, że uciekanie się do filozofii jest czymś daremnym, okazała się stanem najbardziej filozoficznym z możliwych ${ }^{27}$, dając mu do zrozumienia, że więcej można nauczyć się podczas jednej bezsennej nocy niż przez cały rok życia uporządkowanego i wypełnionego kontrolowanymi rozmyślaniami. Kilka lat, w trakcie których rumuński myśliciel był pozbawiony snu, przyczyniło się do tego, że rozbudził się on na okropność, zaraził duchem negacji oraz zyskał głębokie poczucie odmienności, wykluczenia i samotności wśród ludzi ${ }^{28}$. Jego udziałem stała się również jasność umysłu, pewność niestałości i kruchości rzeczy oraz świadomość złudzeń, w których żyją inni ${ }^{29}$, dzięki czemu mógł sięgać swą myślą głębiej niż wszelka systematyczna refleksja i z pozycji bezstronnego obserwatora krytykować utopijność ludzkich konstruktów, zagłuszających nawoływania tego, co w człowieku nietrwałe i przemijające.

Zdaniem Ciorana, oprócz bezsenności, również negatywny stan nudy jest „minimum nierównowagi” 30 , którego musimy doświadczyć,

${ }^{25}$ W jednym z wywiadów Cioran powiedział: "Chociaż nie jestem wierzący (prawdopodobnie nie wierzę w nic), czuję, że ta absolutna samotność wymaga interlokutora. Jeśli mówię o Bogu, to tylko jako o rozmówcy wśród nocy". Idem, Rozmowy z Cioranem, s. 142.

${ }^{26} \mathrm{~W}$ przypadku Ciorana $\mathrm{z}$ bezsennością wiązały się też stany ekstatyczne, podczas których, jak sam opisuje, ciężar i groza nocy były od czasu do czasu kompensowane wybuchami radości prawie nie do zniesienia. Por. idem, Zeszyty, s. 809.

27 Por. M. Bieńczyk, Herezja i melancholia, w: E. Cioran, Historia $i$ utopia, przeł. M. Bieńczyk, Instytut Badań Literackich, Warszawa 1997, s. 96.

28 Por. E. Cioran, Cahier de Talamanca, s. 31.

29 Por. idem, Les continents de l'insomnie. Entretien avec E. M. Cioran, s. 132.

30 Idem, Rozmowy z Cioranem, s. 179. 
jeśli chcemy zbliżyć się do pewnych istotnych prawd dotyczących człowieka. Rumuński myśliciel bardzo wcześnie, bo już jako pięcioletni chłopiec, zetknął się z doświadczeniem nudy w Drăgăşani, w pewne niedzielne popołudnie ${ }^{31}$, na tyle puste i na swój sposób rozdarte, że okazało się niemożliwe do zapomnienia. Właśnie wtedy narodziła się jego świadomość, tożsamość, dzięki nudzie dowiedział się, kim jest, i wraz z nią nastąpił początek jego refleksji filozoficznej. Po wielu latach wspominał to wydarzenie w następujący sposób:

Ów napad nudy, który przeżyłem jako pięciolatek (1916) pewnego popołudnia, którego nigdy nie zapomnę, był pierwszym i prawdziwym przebudzeniem się mojej świadomości. Od tego popołudnia datują się moje narodziny jako istoty ś w i a d o m e j. Czym byłem przedtem? Tylko istotą. Moje ja zaczyna się od tego pęknięcia i jednocześnie objawienia, znamionującego bodaj dwoistą naturę nudy. Raptem odczułem obecność nicości w mojej krwi, w kościach, w oddechu i we wszystkim, co mnie otaczało. Byłem pusty jak przedmioty. Nie było już nieba ani ziemi, lecz ogromna rozciągłość czasu. Czasu zmumifikowanego. Bez nudy nie miałbym tożsamości. To przez nią i za jej przyczyną dane mi było poznać się. Gdybym jej nigdy nie doświadczył, nie miałbym o sobie pojęcia, nie wiedziałbym, kim jestem. Nuda jest spotkaniem z samym sobą - poprzez postrzeżenie własnej nicości ${ }^{32}$.

Podobnie jak bezsenność, nuda - w ujęciu Ciorana - ma swe korzenie w fizjologii. Autor Pokusy istnienia sam sobie zadaje pytanie, skąd bierze się u niego skłonność do tego stanu, i stwierdza, że wiąże się ona prawdopodobnie z jego temperamentem, narządami, stanem arterii, nerwów i żołądka oraz z chronicznymi dolegliwościami, którymi szczodrze obdarzyła go natura ${ }^{33}$. Jego zdaniem we wszystkich organach, członkach i w każdej komórce ciała musi istnieć jakaś próżnia i wnęka, która ma tendencję do poszerzania się, rośnięcia i zdobywania terenu, i dopóki

31 Pora dnia, w której pojawia się nuda, jest zawsze stała. Dopada ona człowieka zawsze po południu, o godzinie 16. Cioran wyraźnie łączy tutaj nudę z chorobą mnichów - acedią która objawia się smutkiem, zniechęceniem, wyczerpaniem, wrażeniem duchowej pustki, wewnętrznym niepokojem, niezdolnością do bycia tu i teraz oraz przekonaniem o własnej samotności, braku pocieszenia i wsparcia. Tak pojęta acedia jest największym zagrożeniem dla mnicha, gdyż prowadzi do wycofania się z życia, zanegowania wartości i celowości w świecie, a ostatecznie - do odrzucenia miłości bożej i samego Boga. Por. idem, Pokusa istnienia, przeł. K. Jarosz, Wydawnictwo KR, Warszawa 2003, s. 182.

32 Idem, Zeszyty, s. 708-709.

33 W Zeszytach Cioran napisał: „Z wszystkich rzeczy przynależnych jakoby sferze "psychicznej« nic nie jest tak związane z fizjologia, jak nuda. Czuje się ją w ciele, we krwi, w kościach, w każdym organie z osobna. Gdyby dać jej wolną rękę, zdemolowałaby nawet paznokcie". Ibidem, s. 270. 
ta przestrzeń jest obojętna, dopóty nie wiemy, czym jest nuda ${ }^{34}$. Uznaje ją za wzorcowy typ cierpienia nieumiejscowionego, które jest wszędzie i nigdzie, i zapewnia, że w jego przypadku jest ona czymś wrodzonym, z nią przyszedł na świat, a nawet ona go poprzedza, gdyż nudził się już $\mathrm{w}$ łonie matki ${ }^{35}$. Mimo to nie sprowadza jej do nudności i złego samopoczucia, lecz nadaje jej status pojęcia filozoficznego ${ }^{36}$, ściśle związanego z zagadnieniami egzystencjalnymi, epistemologicznymi oraz ontologicznymi.

Nuda wpisana jest w świat i ludzką kondycję, a całe życie wydaje się tylko permanentną ucieczką przed nią z małymi przerwami na spotkanie $\mathrm{z}$ ciszą i własną samotnością, których nie mąci hałas codzienności. W przypadku zwykłego człowieka nie ma rzeczy bardziej nieznośnej niż stan monotonnego spoczynku, bez jakiegokolwiek zajęcia, rozrywek i namiętności, gdyż odczuwa on wtedy z całą wyrazistością swą istotową samość, pustość, próżnię, niewystarczalność oraz zależność. Nie potrafi żyć bez zagospodarowywania swego istnienia sprawami, ludźmi i nieustannym dzianiem się i w związku z tym, by nie popaść w bezczynność zmuszająca go do refleksji na temat złowrogich prawd życia oraz oddalić poczucie pustki i bezsensu, stara się uciekać na każdym kroku w codzienną krzątaninę ${ }^{37}$. By dostąpić szczęścia, gnany pragnieniem, wciąż stawia przed sobą nowe cele, a kiedy już je zrealizuje i zwalczy wszelkie przeciwności losu, owe cele okazują się czymś błahym i pozbawionym znaczenia, a osiągnięty spokój, rodząc nudę, staje się nie do zniesienia. $\mathrm{W}$ bezustannym zgiełku, zawieszony między pragnieniem a spełnieniem, poszukuje istnienia zadowalającego i pełnego, które ostatecznie nigdy do końca nie spełni jego oczekiwań, gdyż nie ma ucieczki przed nudą. Jedyne, co mu pozostaje, to zmniejszać niedogodności z nią związane przez skracanie przerw między zaspokojeniem a wyznaczeniem nowego celu ${ }^{38}$. Jeśli szybko nie pojawi się nowe pragnienie, to jego życie natychmiast zostanie zawłaszczone przez nudę, która osuszy „fontanny istnienia" ${ }^{\prime 39} \mathrm{i}$ pogrąży go w jałowym letargu.

34 Por. idem, Święci i łzy, s. 131.

35 Por. idem, Zeszyty, s. 461.

36 W rozmowie z Almirą Cioran powiedział: „odczucie pustki, poprzedzające nudę albo będące nią, przekształca się w doznanie ogólne obejmujące wszystko, skutkiem czego znika jego podstawa organiczna. Ale pomniejszanie wagi tej podstawy jest szalbierstwem". Idem, Rozmowy z Cioranem, s. 101.

37 Zdaniem Ciorana historia ludzkości zaczęła się właśnie dzięki nudzie. Kiedy człowiek uzyskał świadomość, znudzony byciem samym sobą, skierował się ku działaniu i tworzeniu, które przesłoniły pustkę niewypełnionej niczym egzystencji. Por. idem, Zmierzch myśli, s. 234.

38 Por. M. Bizior-Dombrowska, "Pierwszy stopień wykorzenienia ze świata" - nuda Ciorana, w: Cioran - w pułapce istnienia, red. S. Piechaczek, Zakład Poligraficzny Sindruk, Opole 2014, s. 79-96.

39 Por. E. Cioran, Zmierzch myśli, s. 175. 
Nuda Ciorana jest jednak czymś o wiele bardziej fundamentalnym niż w przypadku przeciętnych ludzi. Rumuński myśliciel nie sprowadza jej wyłącznie do niewygody, towarzyszącej momentom braku dążenia lub następującej po chwilach przesytu, lecz mówi o nudzie esencjalnej, organicznej, metafizycznej, bez przyczyny i przedmiotu, która osiąga w jego myśli rozmiary zasady istnienia i jako pustka czy też owa próżnia wydrążająca nie tylko ciało człowieka, ale również całość materii, jest podstawowym elementem struktury świata, stanowi niezbywalną cechę wszystkich bytów, łącznie z człowiekiem ${ }^{40}$. Tak pojęta, nie da się rozproszyć rozrywkami, nie jest też chwilowym kryzysem, przejściowym stanem emocjonalnym, organiczną przygodą czy metafizycznym epizodem, lecz "chorobą nieusuwalną par excellence"41, ujarzmia całe jestestwo i towarzyszy człowiekowi wszędzie, bez względu na miejsce i czas. W jednym z wywiadów Cioran stwierdził:

Doświadczenie nudy, nie pospolite poczucie braku towarzystwa, lecz nudy absolutnej, było ważne. Gdy człowiek czuje się opuszczony przez przyjaciół, to nic takiego. Nuda jako taka pojawia się bez przyczyny, nie pozostawia skutków zewnętrznych. Związane jest z tym poczucie pustego czasu, coś w rodzaju pustki, którą zawsze znałem ${ }^{42}$.

Pierwsze wrażenie, jakiego doznajemy przy okazji doświadczenia nudy, dotyczy czasu i polega na tym, że - podobnie jak w przypadku bezsenności - ulega on zawieszeniu i znieruchomieniu ${ }^{43}$. Kiedy tylko się nudzimy, zatrzymuje on swój bieg i z udręką smakujemy jego milczącą obecność, podobni do zegarów, które stoją i wiedzą o tym, że stoją ${ }^{44}$. Uczestniczymy w jakiejś dziwnej czasowości, w której każda sekunda gęstnieje i kurczy się do jednej nieznośnej chwili, zajmującej miejsce wieczności, niebędącej jednak przekroczeniem czasu, lecz jego ruiną. Stajemy oko w oko z czasem zmęczonym, przeżytym, pozbawionym upływu i następstwa ${ }^{45}$, który jest nieustanną teraźniejszością i monotonią powtarzających się w nieskończoność identycznych momentów. Chwile zostają pozbawione treści i znaczenia, przetaczają się, ale ich bieg jest nam obcy. Już nie pozwalają nam odkrywać w świecie i sobie niczego nowego, a ich charakter sprawia, że wszystko wokół kamienieje

40 Por. idem, Święci i tzy, s. 132.

41 Idem, Zeszyty, s. 786.

42 Cyt. za: B. Mattheus, Cioran. Portret radykalnego sceptyka, przeł. R. Reszke, Wydawnictwo KR, Warszawa 2008, s. 33.

43 "Nuda jest najbardziej elementarną formą zawieszenia czasu, tak jak ekstaza jest jego formą najwyższą i najbardziej złożoną". E. Cioran, Święci i łzy, s. 131.

44 Por. ibidem.

45 W Zmierzchu myśli Cioran napisał: „Muzyka nudy rodzi się z drżenia czasu, z głuchych tonów jego zaniku". Idem, Zmierzch myśli, s. 210. 
i nie zachodzą żadne zmiany. Wszelkie potencje istnieją jako zaktualizowane, a to, co pojawia się na horyzoncie, natychmiast zmienia się w stare i przebrzmiałe lub w żaden sposób nieróżniące się od przeszłego ${ }^{46}$. Wszystko się wyrównuje, nie ma już szczytów ani otchłani odczuć i myśli, lecz jedna, wielka, płaska równina, na której brakuje drogowskazów i jakichkolwiek punktów oparcia. W ten sposób pustce czasu zaczyna towarzyszyć pustka abstrakcyjnego serca, przez które czas już przepłynął, pustka w wymiarze duchowym, aksjologicznym i metafizycznym ${ }^{47}$. Są one dwoma zwierciadłami, które odbijają wzajemnie swą nieważność, bezznaczeniowość i nieobecność ${ }^{48}$. W rozmowie z Fernando Savaterem Cioran stwierdził:

Nuda to zawrót głowy, ale spokojny, mo o o t on ny; to objawienie powszechnej nieważności, to pewność granicząca wręcz z osłupieniem bądź najwyższym jasnowidzeniem, że nie można, nie powinno się nic robić na tym świecie ani na innym, że nie ma na świecie nic, co mogłoby nam odpowiadać bądź nas zadowolić ${ }^{49}$.

Czas, zatrzymując się na teraźniejszości, pociąga za sobą również materię i wysysa z rzeczy "soki” aż do momentu, kiedy staną się przezroczyste. Wskutek tego w przypadku nudy do pustki czasu i serca dołącza się również pustka świata, poczucie jego nicości i bezsubstancjalności ${ }^{50}$. Pustka ta nie ma charakteru biernego, lecz czynny i ekspansywny, jest nieusuwalnym brakiem, gangreną toczącą istnienie i zarażającą wszystko wokół. Jako aktywna zasada „nicościująca”, wyłaniająca się z samych pierwocin bytu ${ }^{51}$, poraża wszechświat nicością, odbiera istnieniu szansę na bycie i przemienia naturę w stan lotny. Co więcej, podczas gdy ludzie kryją się w ideałach, poglądach i tysiącach wierzeń, nuda i towarzysząca jej nicość, pustosząc świat, pustoszą również umysł, czynią go powierzchownym i na swej drodze pozostawiają jedynie strzępy złamanych pojęć, wartości, uczuć i wrażeń, które nie dają już żadnego schronienia

46 Por. M. Bizior-Dombrowska, "Pierwszy stopień wykorzenienia ze świata” - nuda Ciorana, s. 91.

47 „Nuda to rozbrzmiewające w nas echo rozdzierającego się czasu... objawienie pustki, wyczerpanie się tej obłąkanej bredni, która podtrzymuje - lub wymyśla - życie...". E. Cioran, Zarys rozkładu, s. 21.

48 Por. ibidem, s. 20.

49 E. Cioran, Rozmowy z Cioranem, s. 23.

50 „Nuda jest rodzajem chwiejnej równowagi między pustką serca i pustką świata, równowartością tych dwu pustek, które trwałyby w bezruchu, gdyby nie ukryta obecność pragnienia". Idem, Zmierzch myśli, s. 74.

51 „Melancholia, smutek, rozpacz, groza i ekstaza odgałęziają się z potężnego pnia nudy, będącej tedy czymś niezróżnicowanym i pierwotnym. Istnieją k w i a t y melancholii i smutku; ja z upodobaniem myślę o k or zenia ch, gdy mowa o nudzie". Idem, Święci i łzy, s. 132. 
przed istnieniem pozbawionym przyjemnych iluzji. Oderwani od chwil, pozostajemy z chorobliwie jasnym poczuciem czasu, który ma nadejść, w którym będziemy musieli żyć i z którym właściwie nie wiemy, co moglibyśmy poczać. Nic już nas nie interesuje i nic nie przyciąga naszej uwagi, nie jesteśmy też w stanie wysilić się na przeżywanie czegokolwiek, gdyż nie ma już czego przeżywać. Obojętni, nie znajdujemy na zewnątrz siebie nic, co można by przyswoić i co stałoby się źródłem twórczego myślenia i działania. Pozbawieni miłości, szaleństwa i wielkich uniesień, pogrążamy się, toniemy bez powrotu w nicości, w ekstazie niebytu, negatywnej nieskończoności otwierającej się na samą siebie. W najwyższym napięciu i paroksyzmach wewnętrzności zostajemy wrzuceni w samo istnienie, a raczej jego całkowity brak i w tym sensie nuda przyjmuje postać swoistego powrotu do nicości ${ }^{52}$, tragicznego doznania pustki i nieodwracalności istnienia, nieuchronnie zmierzającego do unicestwienia ${ }^{53}$. Ciągła świadomość tego, że na każdym kroku czyha na nas rozpad, zanik, ruina i niebyt oraz że jeszcze przed śmiercią egzystujemy pogrążeni w nicości, czyni z nudy najwyższe doświadczenie tragiczności istnienia.

Ponadto nuda z towarzyszącym jej brakiem intensywności sprawia, że nie jesteśmy ani przygnębieni, ani smutni, lecz przepełnia nas swego rodzaju odczucie nieprzyjemności, spowodowane nie wiedzieć czym w naszych narządach lub przedmiotach zewnętrznych, które to odczucie, zamiast nas zajmować, wywołuje w nas jakąś przedziwną niemoc lub niesmak, do których nie sposób się przyzwyczaić. Jest ona niczym schorzenie, które przeżyliśmy i które pochłonęło wszystkie nasze możliwości, zostawiając nas bezsilnymi i niezdolnymi do zapełnienia pustki po lękach, radościach, cierpieniu i szczęściu. Nic nas nie boli, jednak wolelibyśmy wyraźne cierpienie od tego pozbawionego treści zawieszenia między zdrowiem a choroba, $\mathrm{w}$ nieskończonej, bezprzedmiotowej i rozproszonej rekonwalescencji ${ }^{54}$. Oderwani od czasu i wykorzenieni ze świata, czujemy, że nasze osamotnienie oraz izolacja wzrastają i stają się ciężkie i mdlące, a dni - coraz bardziej absurdalne. Zaczynamy być niewrażliwi na własny los, wyzbywamy się ambicji i już z nikim nie rywalizujemy, nic z tego, co robią i myślą inni, nie obchodzi nas i powoli

52 Zdaniem Ciorana odkrycie, że wszystko jest niczym, jest również początkiem wszelkiej mistyki, gdyż od „Boga do nicości jest mniej niż krok, jako że Bóg to p o z yt y w n y wyraz nicości". W ten sposób nuda nie zawsze jest doświadczeniem deprymującym, niekiedy występują po nim uniesienia, które pustkę zamieniają w pożar towarzyszący ekstazie. Por. ibidem, s. 76.

53 Por. M. Bizior-Dombrowska, "Pierwszy stopień wykorzenienia ze świata” - nuda Ciorana, s. 90.

54 Por. E. Cioran, Zarys rozkładu, s. 22. 
wycofujemy się z życia społecznego i historii ${ }^{55}$. Nasza świadomość separuje się od całej rzeczywistości, musi funkcjonować poza nią jednak nie jest w stanie istnieć sama dla siebie, gdyż może być wyłącznie świadomością stojącą wobec wszechobejmującego bytu ${ }^{56}$. Postawiona poza światem, nie może całkowicie zapomnieć o tym świecie, pragnie znów naiwnie przeżywać, cieszyć się i samorealizować, jednak równocześnie nie jest już zdolna się z nim w żaden sposób utożsamić ani w nim uczestniczyćc ${ }^{57}$. Niemożność dopasowania się do świata sprawia, że rodzi się $\mathrm{w}$ nas poczucie rozdarcia i niespełnienia, przepełnione wstrętem zdziwienie ciałem i świadomościa, odczucie nienaturalności istnienia, obcości, a przede wszystkim pragnienie bycia czymś lub kimś innym gdzie indziej, w jakimkolwiek miejscu i czasie. Ponieważ jednak jest to niemożliwe, nuda daje nam boleśnie odczuć, że jesteśmy skazani na bycie, oraz ujawnia nasze uwięzienie $\mathrm{w}$ istnieniu i świecie będącym otchłanią bez żadnych punktów oparcia ${ }^{58}$. Z tego też względu Cioran może powiedzieć o nudzie, że jest stanem „najwyższego zirytowania światem, które do obrzydzenia egzystencją wprowadza wymiar metafizyczny" 59 .

Zdaniem Ciorana nuda sprawia wrażenie, jakby wszystkiemu nadawała głębię, jednak w rzeczywistości, jako najbardziej jałowe ze wszystkich doświadczeń, niczego nie pogłębia, tylko schodzi w głąb siebie i drąży swoją pustkę ${ }^{60}$. Rumuński myśliciel przyznaje, że to właśnie przez nią nie mógł zdziałać $\mathrm{w}$ życiu niczego poważnego ${ }^{61}$, stworzyć wielkiego dzieła i dzięki niej jego marginalność nie jest czymś przypadkowym, lecz esencjalnym ${ }^{62}$. Co więcej, sądzi, że gdyby niedzielne popołudnia trwały całymi miesiącami lub latami i nikt nie zajmowałby się niczym, ogrom czasu każdą chwilę uczyniłby nieznośną męką, historia dobiegłaby kresu, pozbawiona iluzji ludzkość z przestępstw uczyniła-

55 W Upadku w czas Cioran napisał: „niegdyś żyłem w czasie. [...] Epoka, gdy pozostawałem z nim w zażyłości, jest mi obca, wyprowadziła się z mej pamięci, już nie należy do mego życia. [...] Godny litości, kto niegdyś był w Czasie i nigdy już w nim nie będzie!". Idem, Upadek w czas, przeł. I. Kania, Oficyna Literacka, Kraków 1994, s. 96.

56 Por. B. Suwiński, Potomek Demokryta. Rzecz o wołoskim utrapieńcu, w: W kręu melancholii, red. A. Małczyńska, B. Małczyński, Inicjatywa Wydawnicza „Chiazm”, Opole-Wrocław 2010, s. 55-60.

57 Por. K. Tanalska, Wyprawa po wolność z kamieniem w bucie - Cioran, „Nowa Krytyka" 2010, nr 24/25, s. 135.

58 Por. M. Bizior-Dombrowska, "Pierwszy stopień wykorzenienia ze świata” - nuda Ciorana, s. 89.

59 E. Cioran, Święci i łzy, s. 132.

60 Por. idem, Ćwiartowanie, s. 156.

${ }^{61}$ W liście ze stycznia 1979 roku, wspominając trudności z pisaniem w Dieppe, Cioran oznajmił bratu: „Nuda to przekleństwo, największe, jakie istnieje pod słońcem". Idem, Scrisori către cei de-acasă, s. 175.

62 Por. idem, Rozmowy z Cioranem, s. 23-24. 
by rozrywkę, rozpusta stałaby się prostodusznością, a wrzaski - melodiami ${ }^{63}$. Mimo to, według niego, jedynym głębokim doświadczeniem $\mathrm{w}$ jego życiu była właśnie nuda ${ }^{64} \mathrm{i}$ to ona jest prawdą wszystkiego, czego doświadczamy, a także podstawą tego, czym jest świat i czym jesteśmy my sami ${ }^{65}$. W Zeszytach znajdujemy następujący fragment:

prawda tkwi w nudzie. [...] Nuda nie ma kons zachtów z niczym i nic jej nie oszuka. Rodzi się ona z dystansu wobec każdej rzeczy, z wewnętrznej pustki każdej rzeczy, którą to pustkę odczuwa się jako zło zarazem subiektywne i obiektywne. Tak więc w jej działaniach nie ma żadnej iluzji; spełnia ona warunki badania naukowego. Nuda jest dociekanie m ${ }^{6}$.

Podobnie więc jak u innych egzystencjalistów, również u Ciorana nuda pełni funkcję swoistego nastroju czy też nastawienia poznawczego, które prowadzi od jednego otchłannego odkrycia do kolejnego. Pozbawiona wszystkiego, co powierzchowne, udawane i iluzoryczne, jest jedyną autentyczną postawą egzystencjalna, umożliwiającą właściwe rozpoznanie bytu oraz odkrycie prawd dotyczących kondycji ludzkiej i jako taka może zostać przeciwstawiona istnieniu nieautentycznemu, które polega na ciągłej ucieczce przed nicością i śmiercia, zagłuszaniu strachu i oswajaniu się ze światem przez życie oddane codziennej krzątaninie. Będąc naczelną zasadą istnienia, separuje nas od spraw i rze$\mathrm{czy}^{67}$ oraz zmusza do przyglądania się samym sobie, uświadamiając nam nasze własne istnienie i odrębność. Zatrzymując bieg czasu, ujawnia jego destrukcyjne działanie ${ }^{68}$ oraz wtrąca nas w nicość, pokazując, że nasze życie jest kroczeniem w-pustce-ku-pustce i druzgocąca, przerażającą możliwością niebycia ${ }^{69}$. Przez nią postrzegamy świat jako wyzbyty treści, znikomy i kruchy, a istnienie w nim - jako pułapkę, która po kolei

63 Por. idem, Zarys rozkładu, s. 33-34.

64 Por. idem, Zeszyty, s. 27.

65 W jednej z notatek Cioran stwierdził: „Nudo, nudo - jestem twym najwierniejszym z w ol e n n i ki e m". Cyt. za: B. Mattheus, Cioran. Portret radykalnego sceptyka, s. 214.

66 E. Cioran, Zeszyty, s. 466.

${ }^{67}$ "Znużenie separuje człowieka od świata i rzeczy. [...] Znużenie jest główną organiczną determinantą poznania, rozwija bowiem warunki niezbędne do odróżnienia człowieka od świata”. Idem, Na szczytach rozpaczy, s. 61.

${ }_{68}$ W rozmowie z Michaelem Jakobem Cioran stwierdził: „Ostatecznie nuda skupia się na czasie, na grozie czasu, na lęku przed czasem, na objawieniu i świadomości czasu. [...] Życie można znieść pod warunkiem, że nie jest się świadomym każdej upływającej chwili. Inaczej koniec z nami. Doświadczenie nudy to świadomość rozpaczliwego czasu". Idem, Rozmowy z Cioranem, s. 241.

69 Por. M. Bizior-Dombrowska, "Pierwszy stopień wykorzenienia ze świata" - nuda Ciorana, s. 93. 
odbiera nam wszystko, co w życiu wartościowe, by ostatecznie zabrać nam to życie. Jako stan najwyższej świadomości daje nam w pełni odczuć absurd istnienia porzuconego, samotnego, zdanego wyłącznie na siebie i zmierzającego do nieuchronnego końca ${ }^{70}$.

Zarówno bezsenność, jak i nuda są cenne dla Ciorana ze względu na towarzyszący im aspekt poznawczy, do którego nie mają dostępu ci, co śpią spokojnie lub oddalają chwile pustki, zatracając się w nieustannym dążeniu do spełniania pragnień. Stany te prowadzą do uzyskania nadmiernie wyostrzonej świadomości, która raz nabyta, zakorzenia się niezwykle mocno i w każdej okoliczności życia niejako zmusza nas do widzenia świata „na wskroś"71 oraz nie pozwala na powtórne, naiwne przeżywanie codzienności. W rozmowie z Sylvie Jaudeau Cioran powiedział:

Skrajna trzeźwość spojrzenia jest najwyższym stopniem świadomości, daje odczucie, że się do cna opróżniło wszechświat, że się go przetrwało. $\mathrm{Ci}$, którzy nie przeczuli tego etapu, nie mają pojęcia o szlachetniejszej odmianie rozczarowania, a więc poznania ${ }^{72}$.

„Skrajna trzeźwość spojrzenia" prowadzi z kolei do sceptycyzmu" który w XX wieku właśnie w myśli Ciorana uzyskał swój najdoskonalszy wyraz oraz dodatkowo wzmocnił pesymistyczną postawę rumuńskiego myśliciela ${ }^{74}$. Autor Zarysu rozkładu, w przeciwieństwie do wielu innych sceptyków, uniknął jednak pułapek, w które wpadli zwolennicy tego stanowiska, niezdający sobie sprawy z kruchości jego podstaw teoretycznych. Zakładając, że niczego nie można przyjmować na wiarę, jednocześnie milcząco uznają oni, że tylko postawę sceptyczną należy przyjąć w ten sposób. Nie tłumacza, dlaczego wyłącznie ona ma być prawomocna, i wykluczają wszystkie inne, sami nie wystawiając się na próbę. Jak podkreśla Cezary Rowiński, to niedomaganie teoretyczne rodzi sceptycyzm chory na jedno oko, który krytykuje i demaskuje tradycję oraz konstrukcje społeczne, jednak sam jest naiwny wobec siebie, odgradza się od krytyki z zewnątrz i nie ma w nim miejsca na wątpliwo-

70 Jedynym, choć chwilowym, lekarstwem na nudę była, zdaniem Ciorana, praca fizyczna. Por. E. Cioran, Zeszyty, s. 485.

71 Idem, Zmierzch myśli, s. 191.

72 Idem, Rozmowy z Cioranem, s. 179.

73 W Zeszytach Cioran napisał: „W moim życiu naprawdę liczyły się owe noce, kiedy to moje pewności waliły się jedna po drugiej". Idem, Zeszyty, s. 168. Z kolei w innym miejscu stwierdził: "Nuda jest afektywnym równoważnikiem Wątpienia. (Można by także powiedzieć: Nuda przygotowuje się do sceptycyzmu, jest dlań glebą)". Ibidem, s. 421.

74 „Sceptycyzm to niemal centralny punkt moich pytań. Kto chciałby napisać o mnie coś trafnego, powinien przeanalizować jego rolę w całokształcie moich zainteresowań i obsesji". Ibidem, s. 799. 
ści związane z jego działalnością teoretyczną i praktyczną ${ }^{75}$. Ponieważ Cioran dostrzegał granice i niemoc tego stanowiska, jego sceptycyzm jest krytyczny wobec samego siebie ${ }^{76}$ oraz wobec wszystkich dziedzin życia osobistego i społecznego, które podkopuje i tym samym pozbawia człowieka życiodajnych iluzji ${ }^{77}$. W rozmowie z Jean-François Duvalem rumuński myśliciel stwierdził:

Upraszczając, można by powiedzieć, że mam obsesję nicości czy raczej pustki. To - owszem. Ale nie, że jestem nihilistą. [...] Można by więc powiedzieć, że jestem nihilistą w sensie metafizycznym. Ale nie, nawet to nic nie znaczy. Chętniej już akceptuję termin "sceptyk" - choć fałszywy ze mnie sceptyk. Właściwie nie wierzę $\mathrm{w}$ nic i chyba w tym kierunku... Ale nie, nawet to nie jest prawdą ${ }^{78}$.

O specyfice sceptycyzmu Ciorana decyduje również siła zaangażowania, z jaką rumuński myśliciel poświęca się wątpieniu. Sceptycyzm w odniesieniu tylko do świata nie jest dla niego tym właściwym, gdyż najwartościowszy i niosący najwięcej objawień w sensie egzystencjalnym okazuje się ten w stosunku do samego siebie. Skupiając się na człowieku, a nie na przedmiotach, unika on konwencjonalnych niepokojów i jałowej spekulacji, co sprawia, że uczestniczymy w nim całością swego jestestwa. Jego postawa nie jest rodzajem zwątpienia intelektualnego, a więc rezultatem umysłowej udręki czy też abstrakcyjnej niepewności, odnoszącej się do problemów poznania lub kwestii logicznych, lecz wątpieniem organicznym i totalnym, które rodzi się z wewnętrznych tragedii związanych z niedoskonałością pierwiastka materialnego i przemijaniem oraz z klęsk spowodowanych niemożnością spełnienia pragnień. Jest to sceptycyzm przesiąknięty doświadczeniem tragizmu, zrozpaczony, który po rozważeniu zasadniczych problemów i uznaniu ich nierozwiązywalności, przy jednoczesnej wszechwładzy śmierci, wzbudza smutek, trwogę i niepokój w obliczu świata zredukowanego do pustki ${ }^{79}$.

75 C. Rowiński, Cioran albo granice sceptycyzmu, „Literatura na Świecie” 1978, nr 2, s. $144-145$.

76 O tym, jak bardzo świadomy był Cioran swego sceptycyzmu, świadczy m.in. ten fragment: „nie mógłbym być politykiem, bo wierzę w katastrofę. [...] Jeśli jednak jestem prawdziwym sceptykiem, to nawet katastrofy nie mogę być pewien...". E. Cioran, Rozmowy z Cioranem, s. 22.

77 Por. W. Klimczyk, Emila Ciorana sprawa z Bogiem, czyli religijność bez religii, „Nomos" 2006, nr 55/56, s. 85.

78 E. Cioran, Rozmowy z Cioranem, s. 36.

79 W Świętych i łzach Cioran napisał: „Filozof ratuje się przed tuzinkowością jedynie poprzez mistycyzm lub sceptycyzm, dwie formy rozpaczy w obliczu poznania. Mistyka jest ucieczką z poznania, a sceptycyzm - poznaniem bez nadziei. W żadnej z tych sytuacji św iat nie jest rozw i ąz a n i e m". Idem, Święci i łzy, s. 57. 
Według Ciorana w ostatecznej analizie sceptycyzm bierze się głównie stąd, że nie możemy się spełnić w tym, czym chcielibyśmy być, co chcielibyśmy czuć i zrealizować. Jest więc czymś w rodzaju osadu pozostałego po rozczarowaniach; wypływa z naszych ułomności i doświadczeń, z całego szeregu wrodzonych niemożności, które dały nam znać, że nie przychodzi on znikąd i nagle, nie jest dobrowolny ani nie wybieramy go, tylko wpadamy weń bez możliwości wymknięcia się mu ${ }^{80}$. Jako taki nie jest wyłącznie ćwiczeniem intelektualnym czy też próbą zachowania dystansu wobec rzeczy i zdarzeń, lecz cykliczną choroba, zapisanym grubą linią świadectwem naszej niedoskonałości i naszych ograniczeń ${ }^{81}$ w obliczu wielkich planów i pragnień. W związku z tym jest wyrazem pokory i złamanej dumy, ale również karą jaką wymierzamy nieosiągalnym ideałom, sobie samym i światu za to, że nie są w stanie spełnić naszych oczekiwań i zmuszają nas do zatrzymania się wpół drogi. Sceptyk mści się na wszystkim, o co zabiegał, miota oskarżenia przeciwko ideałowi, którego nie mógł dosięgnąć, poniża go i ośmiesza, chłoszcząc jednocześnie samego siebie i czyniąc ze sceptycyzmu sposób maskowania własnej frustracji i rozpaczy ${ }^{82}$. Ostrożny i czujny do granic możliwości, choćby chciał, nie może już być naiwny, gdyż jego wątpliwości powiększają się o wszystko, co znajdzie się w kręgu jego zainteresowań, a nawet o to, co jest z tymi wątpliwościami sprzeczne lub je zwalcza. Sceptycyzm, pełniąc najpierw funkcję narzędzia czy metody, wnika w niego, staje się jego fizjologia, przeznaczeniem i zasadą zrośniętą z trzewiami. Związany z tym, co najbardziej osobiste, gdy raz zawładnie jego ciałem i umysłem, będzie już zawsze towarzyszył wadom i zaletom, uosobi się i przyjmie formę stosowną do temperamentu swego nosiciela.

W odróżnieniu od sceptyka zwykły człowiek tworzy wartości, by przypisać im obiektywne istnienie, choć w rzeczywistości są one dziełem jego wyobraźni i niepohamowania. Wypełnia swe życie poszukiwaniem „absolutów”, które następnie uznaje za swoje, które kierują jego życiem i które odrzuca dla nowych, dających mu tak samo intensywne, aczkolwiek złudne poczucie pewności. Wciąż przewartościowując hierarchię uznawanych przez siebie wartości, nie jest w stanie, a nawet nie chce, zawiesić sądu o nich i dokonuje ciągłych wyborów między nimi, by móc na ich podstawie działać. Żeby „żyć i oddychać”, przymusza się

${ }^{80}$ W Zeszytach znajduje się następujący fragment: „Jestem sceptykiem z racji fizjologii, dziedziczności, nawyku i inklinacji, a także upodobań filozoficznych". Idem, Zeszyty, s. 102.

${ }^{81}$ „Mój sceptycyzm jest najpierw organiczny, potem intelektualny. To wytwór mojej najintymniejszej chemii, rzecznik mych organów". Ibidem, s. 543.

${ }_{82}$ Cioran podkreślał, że jedynym pragnieniem jego młodości było nadludzkie szczęście, i był pewien, że zostanie mistykiem. Kiedy jednak wygasły w nim porywy żarliwości, uczepił się sceptycyzmu, za pomocą którego zakwestionował ich wartość i zredukował do statusu zmiennych nastrojów. Por. ibidem, s. 552. 
do wiary, że jego świat i pojęcia są prawdziwe, a nawet żąda od innych wyrzeczeń, zbrodni i śmierci, by zdobyć niezachwianą pewność, że się w żaden sposób w swej wierze nie pomylił. Potrzebując punktu oparcia, bezpiecznej przystani i prawdy lub wartości, która mogłaby się stać źródłem siły i działania, na każdym kroku oddaje się w jarzmo, służbę i niewolę. W ten sposób ludzkość przez tysiąclecia trwoni swą energię, przechodzi od przekonania do przekonania, od dogmatu do dogmatu, od iluzji do iluzji, bardzo rzadko oddając się chwilom odpoczynku po zmęczeniu wiarą ${ }^{83}$.

Sceptyk, podobnie jak inni ludzie, również chciałby radować się i cierpieć dla iluzji umożliwiających życie, ale jako męczennik zdrowego rozsądku i trzeźwego spojrzenia nie potrafi tego ${ }^{84}$. Jego dramat ma początek w momencie, gdy rozumując, uświadamia sobie, że czyni użytek ze swego rozumu, przez co zaczyna odczuwać swoją odrębność względem rozważanych treści i tym samym odebrana mu zostaje możliwość twórczego myślenia. Swoje dociekania uznaje za przypadkowe, a świat pojęć i wartości, wytworzony przecież wyłącznie przez jego umysł, jawi mu się jako czysta gra konwencji. Jego myśli zaczynają się zwalczać i neutralizować do tego stopnia, że nie potrafi już znaleźć odpowiedzi na pytanie, dlaczego miałby wybrać raczej tę wartość niż inną. Wszystkie propozycje wydają mu się równie czcze i dowolne, każda zaś zgoda i przyzwolenie - tak samo niezrozumiałe i niedorzeczne. Pozbawiony punktów orientacyjnych i trwałych przekonań, postrzega świat jako miejsce, gdzie nic nie jest wyróżnione i nic nie ma pierwszeństwa, wszystkie prawdy i wartości równoważą się, a następnie, $\mathrm{w}$ tym samym stopniu arbitralne i umowne, zostają zredukowane do rzędu fikcji, z których nie można już wywieść moralności ani reguł postępowania.

W konsekwencji sceptyk popada w stan czystej nieokreśloności, w którym nie może już żywić żadnych przekonań, podzielać jakichkolwiek opinii czy też opowiadać się po którejś ze stron. Podczas gdy inni potrafią w odpowiednim momencie zatrzymać się i nie zgłębiają problemów aż do dna, gdyż to doprowadza intelekt do bankructwa, on - raz odkrywając pustkę $e^{85}$ tam, gdzie do tej pory „zakwitały" byty - nie może już być ślepy na iluzje i powoli pogrąża się w całkowitej jałowości. Jego rozum podkopuje własne fundamenty, drąży samego siebie i nie mogąc oddać się bez reszty żadnej sprawie, zaczyna "dreptać" w jednym miejscu, zżerany przez czczość i daremność wszystkiego. Rozsierdzony i pozbawiony możliwości aktywnego uczestnictwa w świecie, sceptyk

83 Por. E. Cioran, O niedogodności narodzin, s. 82.

84 Por. idem, Sylogizmy goryczy, przeł. I. Kania, Wydawnictwo Aletheia, Warszawa 2009 , s. 38.

85 W Zeszytach Cioran zanotował: „P r ó żn i a: jedyny k o n k ret n y wniosek, do którego doprowadził mnie sceptycyzm". Idem, Zeszyty, s. 487. 
odrzuca każdą postać oczywistości, ponieważ każda oczywistość wypływa z bytu, od którego został oddzielony ${ }^{86}$. Nie dba już o równowagę myśli i zachowanie podstawowych przesądów, nie ma nic do stracenia i chronienia, nie szanuje żadnych tajemnic i zakazów. Mając na uwadze jedynie całkowitą wolność od błędu i strach przed popadnięciem w śmieszność negacji ${ }^{87}$ lub afirmacji, bez reszty uczciwy na płaszczyźnie filozoficznej, sonduje pewności, by je skompromitować oraz stara się doprowadzić do ruiny wszystko, co społecznie uświęcone. Nieprzejednany i rygorystyczny, widzi kłamstwo wszędzie, gdzie ma do czynienia z czymś innym niż obojętnośćs ${ }^{8}$.

Po podważeniu wszystkiego, zlikwidowaniu wszelkich pytań i odpowiedzi oraz zerwaniu łączności z ludźmi i rzeczami sceptyk nie ma już w co wątpić i zawiesza swój sąd ${ }^{89}$. Ponieważ rygorystyczne i konsekwentne wątpienie jest nie do pogodzenia z życiem, staje się umarły jeszcze przed śmiercią i ponosi klęskę. Ostatkami sił próbuje jeszcze upodobnić się do innych, ponownie zaczyna akceptować pozory, a jego mądrość zamienia się w konformizm, jednakże - świadomy wszechobecnej iluzji - nie jest już w stanie utożsamiać jej z rzeczywistością i stąd naśladowanie innych nigdy nie będzie w jego przypadku czymś naturalnym, lecz kwestią planu, strategii i oszustwa. Ostatecznie, nie mogąc zwrócić się w żadną ze stron, zmęczony niszczeniem, tylko obserwuje pochód swych ofiar, pogrąża się w bezczynności, a następnie rozszerza obszar niepewności na samego siebie, zawiesza aktywność umysłu i staje się kimś na poły nierzeczywistym. Osiąga wyzwolenie, ale bez zbawienia, nie drażni go już ani życie, ani śmierć, nic nie pobudza i nic nie intryguje, nieruchomy i bezużyteczny pogrąża się w całkowitej obojętności ${ }^{90}$.

Sceptycyzm Ciorana, w przeciwieństwie do sceptycyzmu rygorystycznego, który wtrąca człowieka w całkowitą pustkę doznań i myśli, można by nazwać sceptycyzmem rozentuzjazmowanym. Rumuński myśliciel nie wątpi bezustannie, lecz wyłącznie od czasu do czasu, pod-

86 "Sceptyk to człowiek najmniej tajemniczy ze wszystkich, a przecież poczynając od pewnej chwili, nie należy on już do tego świata". Idem, Zły demiurg, przeł. I. Kania, Oficyna Literacka, Kraków 1995, s. 89.

${ }^{87}$ Negując, człowiek jest w lepszej sytuacji niż sceptyk. Dla wątpiącego wszystkie cele są tak samo kruche i czcze i z tego też względu nie może się za żadnym opowiedzieć. Natomiast negacja jest życiem dla „niedobrej sprawy”, to cały program mówienia "nie”, demaskowania, który ma w sobie dynamikę oraz może się stać źródłem działania i wypełnić nam codzienność. Nie jest próżnią, lecz niespokojną i agresywną pełnią. Por. idem, Upadek w czas, s. 45.

88 Por. ibidem, s. 34-36.

89 "Skoro zawiesiłem mój sąd, a nawet wątpliwości, pozostaje mi tylko zawiesić krew". E. Cioran, Zeszyty, s. 197.

90 Por. idem, Upadek $w$ czas, s. 39-40. 
czas kryzysów, kiedy - tak samo jak sceptyk ortodoksyjny - zawiesza swój sąd i znosi doznania. Kryzysy te są jednak szybko przezwyciężane i z paraliżu ducha i ciała natychmiast wznosi się on na poziom olśnienia, radosnego uniesienia czy też entuzjazmu, który za pośrednictwem pełnej liryzmu mieszaniny myśli i uczuć jest w stanie ożywiać nawet minerały ${ }^{91}$. Zasób energii, witalności i swego rodzaju barbarzyństwa sprawia, że w dalszym ciągu pozostaje on sam na sam z triumfująca pustka, jednak - dzięki bujności swego wnętrza - zachowuje jednocześnie wolność i dystans wobec ostatecznych wniosków, do których doprowadziło go wątpienie ${ }^{92}$. Ponadto żywotność rodzi w jego przypadku świadomość ironiczną, która oszczędzając mu losu sceptyka ortodoksyjnego, skłania go do uśmiechu nad otchłanią i zadrwienia z samego siebie ${ }^{93}$. W ten sposób rumuński myśliciel okazuje się pozostawać nie tylko poza wszystkim, ale również ponad wszystkim i podobnie jak Kiryłow mówił o Stawroginie, że "gdy wierzy, nie wierzy, że wierzy, a gdy nie wierzy, nie wierzy, że nie wierzy"94, tak my moglibyśmy powiedzieć o Cioranie, dodając - „i drwi”. Właśnie dzięki temu jego sceptycyzm może być sceptyczny wobec samego siebie, a nawet można go nazwać mianem sceptycyzmu zdystansowanego wobec własnego dystansu. W rozmowie z Sylvie Jaudeau Cioran określił w następujący sposób, czym jest dla niego sceptycyzm:

Jest to wieczne zapytywanie, instynktowne odrzucenie pewności. Sceptycyzm to postawa wybitnie filozoficzna, ale - paradoksalnie - nie wynik żadnej procedury, lecz coś wrodzonego. $\mathrm{W}$ istocie sceptykami rodzimy się. Co zresztą nie przeszkadza, byśmy ulegali porywom powierzchownego entuzjazmu. Ludzie myślą na ogót, że jestem pasjonatem, i bez wątpienia jest to prawda na pewnym poziomie, ale gdzieś w głębi pozostaję sceptykiem i właśnie ta głębia, ta zdolność do kwestionowania wszelkich pewników jest naprawdę ważna. Żeby działać, niewątpliwie potrzebujemy pewności. Tyle że najmniejsza refleksja obraca w ruinę to spontaniczne przyzwolenie. W końcu zawsze stwierdzamy, że nie ma nic stałego, żadnego fundamentu. Sceptycyzm albo supremacja ironii ${ }^{95}$.

Czytając dzieła Ciorana, mamy wrażenie, że wprost delektuje się on swym sceptycyzmem, pragnie swych wątpliwości i chce, by było ich jak

91 Por. ibidem, s. 41.

92 „Witalność, nawet bardzo osłabiona, zawsze ma w sobie dość mocy, by na jakiś czas zwalczyć ten pociąg, jaki człowiek żywi do nicości". E. Cioran, Samotność i przeznaczenie, przeł. A. Dwulit, Wydawnictwo KR, Warszawa 2008, s. 132.

93 Porównując się z Nietzschem, Cioran stwierdza, że jego przewaga polega na tym, że w przeciwieństwie do niemieckiego filozofa - stać go na formę sceptycyzmu, jaką zakłada humor. Por. idem, Zeszyty, s. 707.

94 Cyt. za: idem, Pokusa istnienia, s. 14.

95 Idem, Rozmowy z Cioranem, s. 183. 
najwięcej ${ }^{96}$. Twierdzi, że nieporównanie łatwiej byłoby mu funkcjonować bez śladu wiary niż bez śladu wątpliwości i że w jego przypadku sceptycyzm jest jak narkotyk lub trucizna, które pozwalają mu żyć i bez których musiałby sięgnąć po coś silniejszego i bardziej zgubnego ${ }^{97}$. Podobnie jak wiara dla innych, wątpienie jest dla niego potrzebą i pewnością o równie głębokich korzeniach ${ }^{98}$, co ta pierwsza, i gdyby mu ją odebrać, jak sam przyznaje, popadłby w kompletną prostrację ${ }^{99}$. Z tego też względu wydaje się, że tym, do czego dąży, oprócz prawdy, jest także przygoda, brak bezpieczeństwa, niekończące się pytanie, poszukiwanie i wieczne kwestionowanie, a więc odnawianie. Nie przyjmuje żadnego punktu oparcia w postaci skostniałego systemu filozoficznego czy doktryny religijnej i zamiast nich wybiera aktywność, nieufność wobec siebie i rzeczy oraz nieustannie ścierające się ze sobą myślenie i rozważanie. Wątpienie jest dla niego czymś destrukcyjnym, jednak zarazem pożywnym, niszczącą trucizną i wytworem żmii rzucającej się na samą siebie ${ }^{100}$, ale również żmii, która nie jest w stanie żyć bez jadu we własnej krwi ${ }^{101}$. W Złym demiurgu Cioran napisał:

Jeśli z wątpienia uczynimy sobie cel, może ono nieść pociechę równą wierze. Również ono zdolne jest do żarliwości, również ono na swój sposób triumfuje nad wszelkimi niepokojami i ma odpowiedź na wszystko. Skąd więc jego zła reputacja? Otóż stąd, że jest ono rzadsze niż wiara, trudniej osiągalne i bardziej tajemnicze. Nie potrafimy sobie wyobrazić, co się dzieje $\mathrm{w}$ domu watpiciela... ${ }^{102}$

Sceptycyzm, będąc aktem najwyższej odwagi filozofii, pokazał Cioranowi, jak należy wyrzekać się własnych przywiązań i przekonań, oraz w jaki sposób przejść od urzeczeń i buntów do mądrości rezygnacji i zyskać umysłową wolność ${ }^{103}$. Nie pozwalał mu w nic uwierzyć i dzięki temu odpychał od niego wszystko, co mogłoby zagrodzić mu drogę do

96 W Sylogizmach goryczy Cioran napisał: „Nic nie może ugasić mego pragnienia wątpliwości. Ach, mieć laskę Mojżesza, pod której uderzeniem tryskałyby one z opoki!". Idem, Sylogizmy goryczy, s. 31.

97 Por. idem, Zeszyty, s. 413 i 416.

98 W Zlym demiurgu Cioran napisał: "Sceptycyzm jest wi a r ą umysłowości chwiejnych". Idem, Zły demiurg, s. 111.

99 Por. idem, Zeszyty, s. 563.

100 Por. ibidem, s. 675.

101 Cioran napisał o sceptyku: „Wszystko, co podsyca jego głód niezdecydowania, co pomaga mu, a jednocześnie przeszkadza żyć - jest dlań święte". E. Cioran, Upadek $w$ czas, s. 48 .

102 Idem, Zly demiurg, s. 108.

103 „Sceptycyzm zbyt późno zsyła na nas swe błogosławieństwa - na nasze twarze zrujnowane naszymi przekonaniami, na nasze oblicza hien od ideałów". Idem, Sylogizmy goryczy, s. 152. 
pełnego objawień bycia sam na sam ze sobą i niezmąconego przeżywania własnej egzystencji. Umieszczając rzeczy na ich właściwym miejscu i utożsamiając każdą możliwość z błędem, zabezpieczał rumuńskiego myśliciela przed pomyłką ${ }^{104}$ oraz perspektywą wyborów, które są równoznaczne z pogardzaniem prawdą i stanowią źródło nieuzasadnionych konfliktów, walk i cierpień. Dodatkowo był dla Ciorana rodzajem środka uspokajającego, który w trakcie gorączki spowodowanej jakąś drażliwą lub niepokojącą kwestią pokazując, że właściwie nic nie jest warte zainteresowania, a tym bardziej wzburzenia, uspokajał go i pozwalał spoglądać na nią oraz inne kwestie z dużą dozą zobojętnienia:

Narzuciłem sobie filozofię sceptyczna, żeby trzymać w szachu mój nieszczęsny temperament, napady szału i humorzaste reakcje. W każdej chwili muszę brać się w ryzy, hamować moje impulsy, walczyć z napadami gniewu, którym nie wierzę, lecz które wyłaniają się z mej krwi czy też Bóg wie skąd. Sceptycyzm to środek uspokajający, ze znanych mi najbardziej niezawodny. Sięgam po niego w każdej sytuacji, inaczej najdosłowniej bym eksplodowa ${ }^{105}$.

Zarazem jednak, mimo iż sceptycyzm Ciorana był sceptycyzmem rozentuzjazmowanym, ironicznym i podwójnie zdystansowanym, zawsze nakazywał mu uważać siebie za kogoś skazanego ${ }^{106}$. Należy pamiętać, że nadal było to wątpienie całościowe i zupełne, „zgryzota w stanie czystym"107, wątpienie kogoś, kto nie jest już w stanie przymuszać się do wiary w prawdziwość przekonań na temat człowieka i świata. I chociaż duża witalność, jaką charakteryzował się Cioran, nie pozwalała mu pogrążyć się bez reszty w bezczynności ${ }^{108}$, atrofii i pustce, to jednak z czasem przyznawał, że sceptycyzm nadwątlił jego siły i sprawił, że właściwa mu świeżość stała się świeżością starca ${ }^{109}$. Poza tym, stawiając autora Pokusy istnienia w fałszywych sytuacjach, czynił z niego kogoś w rodzaju oszusta. Cioran całe życie trzymał się pozorów, działał jak inni, udawał, że podziela ich przekonania, jednak zawsze zdystansowany wobec wszystkiego, nigdy nie utożsamiał się z tym, co robił i mówił, oraz nie ucieleśniał żadnej postawy czy idei. Chwiejny, nie mogąc stanąć po żadnej ze stron ani związać się z żadnym poglądem i miejscem, pro-

104 „Chcąc mieć pewność, że nie zbłądzimy zanadto, koniec końców najlepiej jest trzymać się okolic sceptycyzmu". Idem, Zeszyty, s. 163.

105 Ibidem, s. 355.

106 Por. E. Cioran, Święci i łzy, s. 167.

107 Idem, Upadek $w$ czas, s. 45.

108 Cioran przyznawał, że trzeźwość spojrzenia była w jego przypadku korygowana przez ambicję i m.in. dzięki temu uniknął bezczynności. Por. idem, O niedogodności narodzin, s. 78.

109 Por. idem, Zeszyty, s. 24, 110, 313, 493, 820. 
wadził „życie bez przekonania" $110 \mathrm{~W}$ nierzeczywistym i pustym świecie, wypełnianym jedynie od czasu do czasu przez uniesienia, ambicje i niejasne, na poły religijne przeczucie/nadzieję, że może jednak nie ma do czynienia z pustka, lecz z tajemnicą.

Ze względu na to, że sceptycyzm Ciorana odnosił się również do rozważań dotyczących kultury i cywilizacji Zachodu, konsekwencją takiego stanowiska jest $\mathrm{z}$ konieczności ontologiczny i historyczny pesymizm, który polega na odebraniu wartości człowiekowi, światu i przyszłości. Wątpienie pokazuje sceptykowi, że wszystko jest przygodne, zbyteczne, każdy zaś wybór jest arbitralny, nic nie posiada racji istnienia, żaden cel nie ma uzasadnienia, a postęp jest tylko jednym z wielu złudzeń ${ }^{111}$. Żyje on w królestwie Nierozwiązywalnego, gdzie zawieszenie sądu zamienia się zawsze $w$ beznadziejne zapytanie, na które nie ma odpowiedzi, nie dlatego, że do tej pory ich nie znaleziono, lecz dlatego, że samo istnienie świata nie ma żadnego usprawiedliwienia. $Z$ takim światem nie łączy go już żadna więź, a pustka, która zajęła miejsce płodnych iluzji, uświadamia mu, że oprócz narodzin, czystego faktu istnienia ${ }^{112}$ wypełnionego cierpieniami i czekającej go śmierci nie ma żadnych innych prawd ${ }^{113}$. Dzięki trzeźwemu spojrzeniu wie on, jak wszystko się potoczy, i nie musi czekać na rozczarowanie ani ostateczną klęskę ${ }^{114}$, gdyż dla niego są one równoczesne z każdym ludzkim uczynkiem ${ }^{115}$.

110 Ibidem, s. 802.

111 Por. T. Chawziuk, Cioran do śmiechu, „Nowy Nurt” 1996, nr 6, s. 16.

112 W jednym z fragmentów Świętych $i$ łez Cioran stwierdził: „Wszystko jest oszustwem, gorzkim i słodkim. Gołym okiem widać, że rzeczywistość ani prawda nie mogły zaistnieć". E. Cioran, Święci i łzy, s. 161.

113 „Czy na tej ziemi jest jeszcze coś - oprócz śmierci, jedynej rzeczy pewnej - czego nie można by podać w wątpliwość?”. Idem, Na szczytach rozpaczy, s. 70. „Bo jakże być optymistą w świecie, w którym nic nie jest pewne, z wyjątkiem śmierci!" Idem, Samotność i przeznaczenie, s. 131.

114 Według Michała Jakubika w myśli Ciorana klęska jest czymś, co w swoisty sposób zawiera się w strukturze człowieka, i tylko kwestią czasu jest to, kiedy go spotka. M. Jakubik, Wątki religijne w twórczości Emila Ciorana, Novae Res-Wydawnictwo Innowacyjne, Gdynia 2012, s. 166.

115 W Zmierzchu myśli Cioran napisał: „Strach jest wspomnieniem przyszłości”. E. Cioran, Zmierzch myśli, s. 179. 


\section{Streszczenie}

\section{Osobowe źródła Cioranowskiego sceptycyzmu i pesymizmu}

\section{Słowa kluczowe}

Egzystencjalizm; pesymizm; sceptycyzm; nuda; bezsenność; czas; pustka; bezsens

Artykuł skupia się na filozoficznej analizie pojęć bezsenności i nudy oraz ich związku ze sceptycyzmem i pesymizmem rumuńskiego myśliciela Emila Ciorana. Według autora Pokusy istnienia bezsenność pozbawia zbawiennych przerw i przez to zmusza do nieustannej i wyczerpującej przytomności umysłu i ciała. Odbierając możliwość regeneracji sił witalnych i naiwne odczucie czasu oraz skrajnie rozbudzając świadomość, czyni człowieka niezdolnym do działania, a także wpędza w poczucie agonii, smutku i rozpaczy. Podobnie nuda, jako stan monotonnego spoczynku, wrzuca w istotową samość, próżnię i pustość oraz zmusza do refleksji na temat złowrogich prawd życia. Poprzez zawieszenie czasu pozbawia ona chwile treści i znaczenia, wpędza człowieka w nieważność i nieobecność, a świat w nicość i bezsubstancjalność. Cechą wspólną stanu bezsenności i nudy jest skrajnie wyostrzona świadomość, prowadząca do sceptycyzmu, który w myśli Ciorana nie odnosi się wyłącznie do świata, lecz przede wszystkim do człowieka. Powstaje on na skutek tragedii związanych z przemijalnością oraz $\mathrm{w}$ związku z niemożnością realizacji pragnień, która wynika z naszych niedoskonałości i ograniczeń. Sceptyk, raz wpadając w pułapkę wątpienia, zmienia się w więźnia trzeźwego spojrzenia. Staje się odrębny względem rozważanych treści, swe dociekania uznaje za przypadkowe, a pojęcia i wartości postrzega jako grę konwencji, w której wszystkie one równoważą się i maleją do rzędu fikcji. Tak rozumiany sceptycyzm doprowadza Ciorana do ontologicznego i historycznego pesymizmu, który polega na odebraniu człowiekowi, światu i przyszłości wszelkiej wartości poprzez uznanie wszystkiego za arbitralne, zbyteczne i nieposiadające racji istnienia.

\section{Summary}

\section{Personal sources of Cioran's skepticism and pessimism}

\section{Keywords}

Existentialism; pessimism; skepticism; boredom; insomnia; time; emptiness; meaninglessness 
The article concentrates on the philosophical analysis of concepts of insomnia and boredom and on their connection with skepticism and pessimism of the Romanian thinker Emil Cioran. According to the author of The Temptation to Exist, insomnia deprives us of salutary breaks and hence forces to a constant and exhausting consciousness of mind and body. By taking away the possibility to regenerate the vital strength and the naïve sense of time and by arousing the consciousness in an extreme manner, insomnia makes the man unable to act and drives him into the feeling of agony, sadness and despair. Similarly boredom, which is a state of monotonous repose, drops us into an existential loneliness, void and emptiness and forces us to reflect upon the subject of the malevolent truths about life. Through suspending time, boredom deprives moments of content and meaning, drives a man into unimportance and absence, while the world into nothingness and non-substantialism. The common feature of states of insomnia and boredom is an extremely heightened consciousness leading to skepticism, which, according to Cioran's thoughts, does not solely refer to the world but primarily to a man. It develops due to tragedies connected with transience and an inability to fulfill desires, which comes from our imperfections and limitations. A sceptic, who once falls into a trap of doubt, changes into a prisoner with a sober look. He becomes separated from the issues he analyses, acknowledges the inquiry as accidental and perceives terms and values as a game of conventions, in which everything becomes equal and reduced to the level of fiction. Understanding skepticism in this way, leads Cioran to ontological and historical pessimism, which deprives mankind, the world and the future of all values through acknowledging that everything is arbitrary, unnecessary and without a reason to exist.

\section{Bibliografia}

Bieńczyk M., Herezja i melancholia, w: E. Cioran, Historia i utopia, przeł. M. Bieńczyk, Instytut Badań Literackich, Warszawa 1997.

Bizior-Dombrowska M., "Pierwszy stopień wykorzenienia ze świata” - nuda Ciorana, w: red. S. Piechaczek, Cioran - w pułapce istnienia, Opole 2014.

Chawziuk T., Cioran do śmiechu, „Nowy Nurt” 1996, nr 6.

Cioran E., Cahier de Talamanca, Éditions Gallimard, Paris 2000.

Cioran E., Ćwiartowanie, przeł. M. Falski, Wydawnictwo KR, Warszawa 2004.

Cioran E., Ćwiczenia z zachwytu, przeł. J.M. Kłoczowski, Spółdzielnia Wydawnicza "Czytelnik”, Warszawa 1998.

Cioran E., Les continents de l'insomnie. Entretien avec E. M. Cioran, w: G. Liiceanu, Itinéraires d'une vie: E. M. Cioran, Éditions Michalon, Paris 1995.

Cioran E., Na szczytach rozpaczy, przeł. I. Kania, Oficyna Literacka, Kraków 1992.

Cioran E., O niedogodności narodzin, przeł. I. Kania, Oficyna Literacka, Kraków 1996.

Cioran E., Pokusa istnienia, przeł. K. Jarosz, Wydawnictwo KR, Warszawa 2003. 
Cioran E., Rozmowy z Cioranem, przeł. I. Kania, Wydawnictwo KR, Warszawa 1999.

Cioran E., Samotność i przeznaczenie, przeł. A. Dwulit, Wydawnictwo KR, Warszawa 2008.

Cioran E., Scrisori către cei de-acasă, Humanitas, Bucureşti 2010.

Cioran E., Święci i łzy, przeł. I. Kania, Wydawnictwo KR, Warszawa 2003.

Cioran E., Sylogizmy goryczy, przeł. I. Kania, Wydawnictwo Aletheia, Warszawa 2009.

Cioran E., Upadek w czas, przeł. I. Kania, Oficyna Literacka, Kraków 1994.

Cioran E., Wyznania i anatemy, przeł. K. Jarosz, Zielona Sowa, Kraków 2006.

Cioran E., Zarys rozkładu, przeł. M. Kowalska, Wydawnictwo KR, Warszawa 2006.

Cioran E., Zeszyty, przeł. I. Kania, Wydawnictwo KR, Warszawa 2004.

Cioran E., Zły demiurg, przeł. I. Kania, Oficyna Literacka, Kraków 1995.

Cioran E., Zmierzch myśli, przeł. A. Dwulit, Wydawnictwo KR, Warszawa 2004.

Jakubik M., Wątki religijne w twórczości Emila Ciorana, Gdynia 2012.

Klimczyk W., Emila Ciorana sprawa z Bogiem, czyli religijność bez religii, „Nomos" 2006, nr 55/56.

Mattheus B., Cioran. Portret radykalnego sceptyka, przeł. R. Reszke, Wydawnictwo KR, Warszawa 2008.

Parfait N., Cioran, ou, le défi de l'être, Éditions Desjonquères, Paris 2001.

Rowiński C., Cioran albo granice sceptycyzmu, „Literatura na Świecie” 1978, nr 2.

Suwiński B., Potomek Demokryta. Rzecz o wołoskim utrapieńcu, w: W kręgu melancholii, red. A. Małczyńska, B. Małczyński, Inicjatywa Wydawnicza „Chiazm", Opole-Wrocław 2010.

Tanalska K., Wyprawa po wolność z kamieniem w bucie - Cioran, „Nowa Krytyka" 2010, nr 24/25. 